\title{
Author Correction: Ketamine disinhibits dendrites and enhances calcium signals in prefrontal dendritic spines
}

\author{
Farhan Ali, Danielle M. Gerhard, Katherine Sweasy, Santosh Pothula, Christopher Pittenger (1), Ronald S. Duman \\ \& Alex C. Kwan (1)
}

Correction to: Nature Communications https://doi.org/10.1038/s41467-019-13809-8, published online 7 January 2020.

The original version of this Article contained an error in Fig. 1g, in which there was an inadvertent duplication of one of the example traces from the set of four cells in the "pre" and "post" conditions. The duplication occurred between the bottom trace under "pre" and the top trace under "post". The figure has been corrected with different example traces from a set of four cells for each part of the figure. New examples were selected because the authors do not have a record of which cell and at which time points the original example traces were selected from. This error has now been corrected in both the PDF and HTML versions of the Article. The raw data underlying this figure is available as a Source Data file and all data underlying the paper is available at https:/github.com/Kwan-Lab/ ali2020.

Published online: 08 January 2021

\section{Additional information}

Supplementary information is available for this paper at https://doi.org/10.1038/s41467-020-20634-x.

\footnotetext{
(c) Open Access This article is licensed under a Creative Commons Attribution 4.0 International License, which permits use, sharing, adaptation, distribution and reproduction in any medium or format, as long as you give appropriate credit to the original author(s) and the source, provide a link to the Creative Commons license, and indicate if changes were made. The images or other third party material in this article are included in the article's Creative Commons license, unless indicated otherwise in a credit line to the material. If material is not included in the article's Creative Commons license and your intended use is not permitted by statutory regulation or exceeds the permitted use, you will need to obtain permission directly from the copyright holder. To view a copy of this license, visit http://creativecommons.org/licenses/by/4.0/.
}

(C) The Author(s) 2021 